\title{
On the action of the discharge of electricity of high potential on solid particles suspended in the air
}

\section{A. Von Obermayer \& M. Von Pichler}

To cite this article: A. Von Obermayer \& M. Von Pichler (1887) On the action of the discharge of electricity of high potential on solid particles suspended in the air, Philosophical Magazine Series 5, 23:142, 301-303, DOI: 10.1080/14786448708628010

To link to this article: http://dx.doi.org/10.1080/14786448708628010

曲 Published online: 29 Apr 2009.

Submit your article to this journal $\square$

Џ Article views: 2

Q View related articles ๘ 
book of reference. The boundary of mathematical science forms, year by year, an everwidening circle, and the advantage of having at band some condensed statement of results becomes more and more evident. To the original investigator occupied with abstruse researches in some one of the many branches of Mathematics, a work which gathers together synoptically the leading propositions in all, may not therefore prove unacceptable." In an undertaking of such magnitude it would not be difficult to detect faults, but these are in the main corrected by the lists of Errata ; and some others, as the unfortunate wrong numbering of a limited number of sections in Section viii., which is indicated on p. 473, are allowed for in the Index. Every subject that can be classed under the head of Pure Mathematics, with the exception perhaps of Quaternions, appears to us to have been carefully treated on the author's lines. A little difficulty is at first experienced in working with such a vast Index; but it will be found with use that this part is as carefully done as the rest of the work. To many of our readers a most useful part will be found to be comprised in that portion which is represented by the closing words of the titlepage, "Supplemented by an Index to the Papers on Pure Mathematics which are to be found in the principal Journals and Transactions of learned Societies, both Finglish and Foreign, of the present Century." These are thirty-two in number, are tabulated with great care, and references to the British Museum Catalogue are appended. This is such a valuable feature of the book that we should like to see the list considerably extended, so as to include for instance references to our own columns, in which from time to time most important articles on Pure Mathematics have been furnished by Cayley, Sylvester, Boole, and others of our leading men.

The typography, arrangement of text, colour of paper, and figures leave little, or we would rather say nothing, to be desired, for readers can consult the book with comfort under almost any light.

\section{Intelligence and Miscellaneous Articles.}

ON THE ACTION OF THE DISCHARGE OF ELECTRICITY OF HIGH POTENTIAL ON SOLID PARTICLES SUSPENDED IN THE AIR. BY A. VON OBERMAYER AND M. VON PICHLER.

THE purification of air from dust by electrical discharges has been 1 observed by Aitken ('Nature,' vol. sxuiii. p. 322), and Lodge (Phil. Mag. [5] xvii. p. 214). The authors have examined the discharges of a double-influence machine in turpentine-smoke; this was contained in a glass tube, 11 centim in diameter and 111 centim. in length, provided with brass mounts. The discharge took place between rods provided with combs at the ends, and which were supported in insulated mounts nearly parallel to the axis of the tube. The smoke was deposited in large flakes near the combs in less than a second. The spark of an induction-coil and of a 
magneto-electrical machine acted more slowly. In like manner, when the brush-discharge was produced from sixteen points in the chimney-pipe of a stove towards the sides, the smoke was almost completely deposited, especially if the points were connected with the negative, and the pipe with the positive electrode of the machine; and two double induction-machines connected together were used.

Kundt's dust-circles were also obtained, when the points and the plate were connected with the poles of an induction-machine, and the discharge continued for some time. They are equal for the two electricities. If the metal disk is not dusted with su'phur or lycopodium until the discharge takes place, dust-rings are formed instead of dust-circles. Here also the rings are equal, whether the point is positive or negative. If the point is very close, dustcircles appear surrounded by an annular surface almost entirely free from dust, and again surrounded by slight dust near the edge of the plate.

With a positive plate 215 millim. in diameter, with a fine negative point at a distance $s$, the magnitude of the rings is as follows $\left(\mathrm{D}_{a}\right.$ and $\mathrm{D}_{i}$ being the outer and inner diameter of the dust-circle or dust-rings, $\mathrm{D}$ that of the dusted surface :-

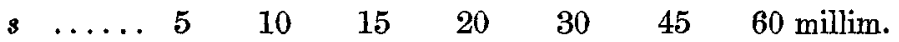

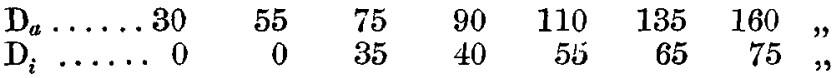

$$
\begin{aligned}
& \text { D .... } 70 \quad 100 \quad 130 \quad 160 \quad>215 \mathrm{~mm} \text {. }
\end{aligned}
$$

The explanation of the various figures is ascribed by the authors to the electrification of the badly-conducting particles of -dust which lie on the plate, and which in consequence adhere to the plate as in Kundt's figures. If to this is added the electrical aura, it blows the particles away from the middle and lodges them towards the edge, where they adhere in consequence of permanent electrification.

If, instead of metal plates, vertical networks of 1 centim. width of mesh are used, a horizontal point being brought to within a distance of 7 centim., while the net and the point are connected with the conductors of two influence-machines connected with each other, and if sulphur-powder is dusted on the net while the brushdischarge takes place from a negative point, a dust-ring is formed of 38 centim. external and 15 centim. internal diameter. If the powder blown through the net is caught on a horizontal paper, a tongue about 15 centim. in width appears free from dust, to which follow zones on each side of tolerably dense powder. With a positive point the same result is obtained, except that the dust-free zone is not so distinct. Lycopodium flies further away.

If a fine point, and a wire gauze of 1 centim. width of mesh, is placed at a distance $s$ parallel in the electrodes of an inductionmachine, and these latter are adjusted at a distance $D$ so that sparks alternately pass between the electrodes, and brush-discharges take place from the point, the following values were obtained for 
the potentials $\mathrm{V}$ corresponding to $s, \mathrm{D}$, and for $\mathrm{V} / \mathrm{D}$ the following numbers :-

\begin{tabular}{|c|c|c|c|c|c|c|c|c|}
\hline D & $\begin{array}{l}2 \cdot 5 \\
0 \cdot 70\end{array}$ & $\begin{array}{l}5 \\
1 \cdot 10\end{array}$ & $\begin{array}{l}10 \\
2 \cdot 37\end{array}$ & $\begin{array}{l}20 \\
4.97\end{array}$ & $\begin{array}{l}30 \\
7 \cdot 47\end{array}$ & & & $\begin{array}{l}50 \text { centim. } \\
8.55,\end{array}$ \\
\hline $3 \bar{V}$ & 23 & 28 & 44 & 60 & 69 & & & \\
\hline & & 25 & 18 & 12 & $9 \cdot 2$ & & & \\
\hline
\end{tabular}

The equivalent striking distances $\mathrm{D}$ approach a limit as $s$ increases; they increase more rapidly than the corresponding potentials.

In the discharge of electricity from points towards a wire gauze, the velocity of the electrical aura could be determined by means of an anemometer placed behind the wire gauze.

When the point was at a distance $s=7$ centim. between the point and the wire gauze, the following velocities, in metres and seconds, were obtained :-

$$
\begin{array}{ccccccc}
\mathrm{D} & \ldots \ldots \ldots & 12 & \mathbf{5} \cdot 7 & 109 & 157 & 207 \text { centim. } \\
\mathrm{V} & \ldots \ldots \ldots & 1 \cdot 71 & \mathbf{1} \cdot 69 & \mathbf{1} \cdot 19 & 0.61 & 0
\end{array}
$$

Hence, by means of the electrical aura, fine particles of dust can be carried to great distances. - Wiener Berichte, xciii. p. 408(1886); Beiblätter der Physik, vol. x. p. 641.

\section{ON A SIMPLE AND CONVENIENT FORM OF WATER-BATTERY.} BY HENRY A. ROWLAND.

For some time I have had in use in my laboratory a most simple, convenient, and cheap form of water-battery, whose design has been in one of my note-books for at least fifteen years. It has proved so useful that $I$ give below a description for the use of other physicists.

Strips of zine and copper, each two inches wide, are soldered together along their edges so as to make a combined strip of a little less than four inches wide, allowing for the overlapping. It is then cut by shears into pieces about one fourth of an inch wide, each composed of half zine and balf copper.

A plate of glass, very thick and a foot or less square, is heated and coated with shellac about an eighth of an inch thick. The strips of copper and zinc are bent iuto the shape of the letter $\mathrm{U}$, with the branches about one fourth of an inch apart, and are heated and stuck to the shellac in rows, the soldered portion being fixed in the shellac, and the two branches standing up in the air, so that the zinc of one piece comes within one sixteenth of an inch of the copper of the next one. A row of ten inches long will thus contain about thirty elements. The rows can be about one eighth of an inch apart, and therefore in a space ten inches square nearly 800 elements can be placed. The plate is then warmed carefully so as not to crack, and a mixture of beeswax and resin, which melts more easily than shellac, is then poured on the plate to a depth of half an inch to hold the elements in place. A frame of wood is made around the back of the plate with a ring screwed to the centre, so that the whole can be hung up with the zinc and copper elements below.

When required for use, lower so as to dip the tips of the ele- 